\title{
Explaining the 'anomalous' distribution of Echinodium (Bryopsida: Echinodiaceae): Independent evolution in Macaronesia and Australasia
}

\author{
Michael Stech $^{\mathrm{a}, *}$, Manuela Sim-Sim ${ }^{\mathrm{b}}$, M. Glória Esquível ${ }^{\mathrm{c}}$, Susana Fontinha ${ }^{\mathrm{d}}$, \\ Ray Tangney ${ }^{\mathrm{e}}$, Carlos Lobo ${ }^{\mathrm{f}}$, Rosalina Gabriel ${ }^{\mathrm{g}}$, Dietmar Quandt ${ }^{\mathrm{h}}$ \\ ${ }^{a}$ Nationaal Herbarium Nederland, Universiteit Leiden branch, P.O. Box 9514, 2300 RA Leiden, The Netherlands \\ ${ }^{\mathrm{b}}$ Universidade de Lisboa, Faculdade de Ciências de Lisboa, Departamento de Biologia Vegetal (DBV), \\ Centro de Biologia Ambietal (CBA), C2, Campo Grande, 1749-016 Lisboa, Portugal \\ ${ }^{\mathrm{c} C e n t r o ~ d e ~ B o t a ̂ n i c a ~ A p l i c a d a ~ a ̀ ~ A g r i c u l t u r a, ~ I S A, ~ 1349-017 ~ L i s b o a, ~ P o r t u g a l ~}$ \\ ${ }^{\mathrm{d}}$ Centro de Estudos da Macaronésia, Serviço do Parque Natural da Madeira. Quinta do Bom Sucesso, 9050-251 Funchal, \\ Madeira, Portugal \\ 'Department of Biodiversity and Systematic Biology, National Museum and Gallery, Cardiff, CF10 3NP, UK \\ fJardim Botânico da Madeira, Quinta do Bom Sucesso, 9050-251 Funchal, Madeira, Portugal \\ ${ }^{\mathrm{g}}$ Departamento de Ciências Agrárias, CITAA, Universidade dos Açores, 9701-851 Angra do Heroísmo, Açores, Portugal \\ ${ }^{\mathrm{h}}$ Institut für Botanik, Technische Universität Dresden, 01062 Dresden, Germany
}

Received 28 March 2007; accepted 25 February 2008

\begin{abstract}
The peculiar disjunction between Macaronesia and Australasia of the morphologically isolated pleurocarpous moss genus Echinodium is one of the most prominent questions in bryology. Echinodium as traditionally circumscribed comprises six extant species, four restricted to the Macaronesian archipelagos and two confined to the Australasian/ Pacific regions. Molecular phylogenetic analyses based on plastid $\operatorname{trn} L_{\mathrm{UAA}}$ intron and nuclear ribosomal ITS sequences indicate that Echinodium is polyphyletic and split into three groups. Three of the four Macaronesian species (E. spinosum and the single island endemics E. renauldii and E. setigerum) are closely related to each other and treated as Echinodium s.str. (Echinodiaceae). Further clarification of the relationships of Echinodium s.str. with Orthostichella, a segregate of Lembophyllaceae, is needed. The remaining Macaronesian species, E. prolixum, is transferred to Isothecium (Lembophyllaceae); this systematic position is also strongly supported by leaf characters. The two Australasian species, E. hispidum and E. umbrosum, are molecularly unrelated to the Macaronesian species and are transferred to Thamnobryum in the Neckeraceae. While the molecular data suggest that the peculiar distribution pattern of 'Echinodium' is an artefact, the striking morphological similarity observed in Macaronesian and Australasian species cannot be dismissed. Possible explanations are: (i) parallel morphological evolution of the 'Echinodium habit' in Macaronesia and Australasia, or (ii) retention of a set of plesiomorphic characters in non-related groups in relict habitats, the Macaronesian laurel forest and the austral temperate rain forests, respectively. Of these hypotheses, the evolutionary parallelism hypothesis seems more plausible for several reasons, which are discussed.

(C) 2008 Gesellschaft für Biologische Systematik. Published by Elsevier GmbH. All rights reserved.
\end{abstract}

Keywords: Biogeography; Echinodiaceae; ITS; Molecular relationships; Pleurocarpous mosses; $\operatorname{trn} L_{\mathrm{UAA}}$ intron

\footnotetext{
${ }^{*}$ Corresponding author.

E-mail address: stech@nhn.leidenuniv.nl (M. Stech).
} 


\section{Introduction}

The Echinodiaceae are a small family of pleurocarpous mosses, comprising only one genus, Echinodium Jur., with six extant species (Churchill 1986). Echinodium shows one of the most peculiar disjunct distribution patterns (Fig. 1), which puzzled bryologists for more than a century. Four species are restricted to the Macaronesian archipelagos, E. prolixum (Mitt.) Broth. to the Azores and Madeira, E. spinosum (Mitt.) Jur. to Madeira and Canary Is., E. renauldii (Card.) Broth. endemic to the Azores, and E. setigerum (Mitt.) Jur. endemic to Madeira. The remaining two species are confined to the Australasian region, E. hispidum (Hook. f. \& Wils.) Reichardt in Eastern Australia, New Zealand and New Caledonia, and E. umbrosum (Mitt.) A. Jaeger in New Zealand, reaching northwards to Fiji (Churchill 1986). A separate, nowadays extinct species, E. savicziae A. Abr. \& I. Abr., was described based on fossils from the Pliocene of Georgia (Abramov and Abramov 1958) and the Miocene of Poland (LancuckaSrodoniowa 1996). These and further fossil finds from the Eocene in Baltic and Saxon amber (Frahm 2004) as well as from the Pleistocene of Tasmania (Jordan and Dalton 1995) indicate an evolutionary old age and a wider distribution of the genus Echinodium in the Tertiary (Fig. 1). This is supported by the predominant occurrence of the extant Echinodium species in relict forest types, the laurel forest (Laurisilva) in Macaronesia, a presumed remnant of the Tertiary flora (e.g., Capelo et al. 2005), and southern temperate rain forests to semi-tropical forests in Australasia. Because of their limited distribution areas all four Macaronesian species are either considered rare or threatened in European or worldwide red lists (ECCB 1995; IUCN 2002), with E. renauldii and E. setigerum classified as "Vulnerable" by IUCN (2002).

The Echinodium species have been well characterised morphologically and ecologically (e.g., Churchill 1986; Hedenäs 1992; Gabriel 1994; Dierßen 2001; Fontinha et al. 2001, 2006). The genus Echinodium is easily recognized by the combination of rather stiff, irregularly pinnate or subdendroid plants, generally long subulate and plicate leaves with partially to fully bistratose

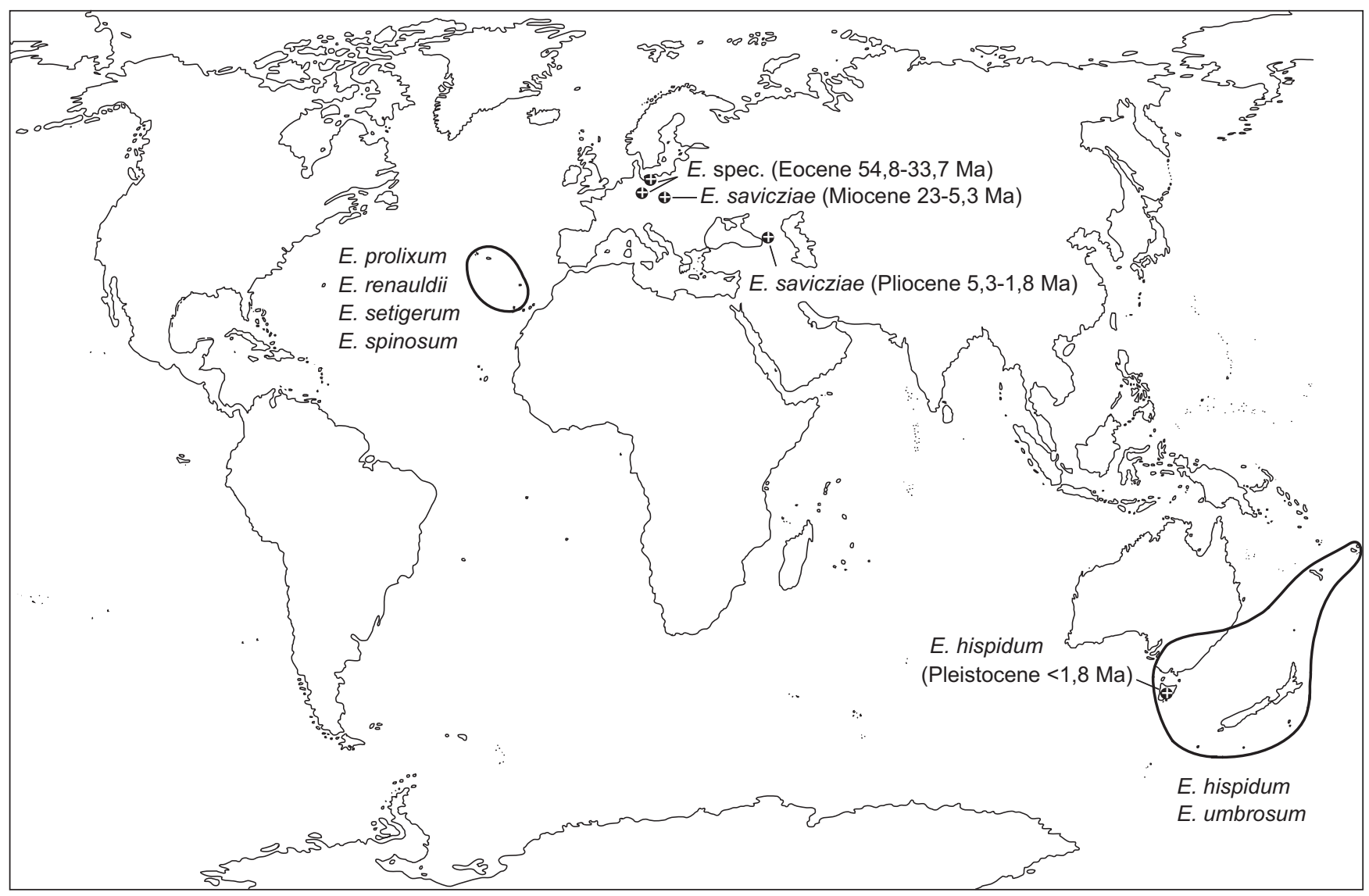

Fig. 1. Extant disjunct distribution of the moss genus Echinodium (bold lines), with names of the species occurring on the Macaronesian islands and in the Australasian/Pacific regions, respectively, as well as locations and ages (in million years before present) of fossil finds assigned to Echinodium. 
margins, percurrent to excurrent costae, and short leaf cells. Despite this characteristic 'Echinodium habit', Churchill (1986) pointed out that the subulate, plicate leaves and bistratose margins are the only morphological synapomorphies, and hypothesised that the species could belong to different genera. Furthermore, the systematic position of Echinodiaceae within the pleurocarpous mosses remains ambiguous. Echinodiaceae have been placed near various pleurocarpous families in the former Isobryales (e.g., Fleischer 1909-1923; Brotherus 1925; Walther 1983) or Hypnobryales (especially the Thuidiaceae; e.g., Robinson 1971; Vitt 1984; Buck and Vitt 1986). Interestingly, none of these authors questioned the monophyly of the family Echinodiaceae or its taxonomic rank. First doubts on the systematic position and rank were put forward by Hedenäs (1992) in his flora of Madeiran pleurocarpous mosses, where he included the Macaronesian Echinodium species in Lembophyllaceae. Echinodium hispidum was resolved as sister to Limbella tricostata (Sull.) Müll. Hal. ex E.B. Bertram (Neckeraceae) in the cladistic analyses of morphological characters by Hedenäs (1995), but relationships of these two species to other isobryalean taxa remained ambiguous.

Based on molecular phylogenetic analyses, the two main pleurocarpous orders (Isobryales/Neckerales/Leucodontales and Hypnobryales/Hypnales) were merged into one, Hypnales (Buck et al. 2000). Resolving familial relationships among pleurocarpous mosses with confidence, however, remains a challenging task (see, e.g., Goffinet and Buck 2004). Echinodiaceae have not been challenged on molecular grounds, as only one species (E. umbrosum) has been included in previous molecular studies of pleurocarpous mosses (Buck et al. 2000; De Luna et al. 2000). These studies were based on different combinations of plastid DNA regions, rps 4 and $\operatorname{trn} L-F$ (Buck et al. 2000) or rps4, trnL-F and $r b c L$ (De Luna et al. 2000), respectively, and indicated a closer relationship of Echinodium umbrosum to either Thamnobryum (Buck et al. 2000) or Lembophyllum (De Luna et al. 2000). However, Thamnobryum was missing in the analyses of De Luna et al. (2000), and the trees in both studies lacked significant support for most clades.

The present study aims at providing the first comprehensive molecular investigation of the enigmatic genus Echinodium. Based on sequences of the plastid $\operatorname{trn} L_{\mathrm{UAA}}$ intron and the more variable internal transcribed spacers (ITS) 1 and 2 of the nuclear ribosomal DNA (nrDNA), we aim (i) to test the monophyly of Echinodium and to evaluate the significance of the morphological characters used to define the genus, (ii) to clarify systematic and evolutionary relationships of the Echinodium species, and (iii) to develop hypotheses that could explain the peculiar extant distribution pattern.

\section{Material and methods}

\section{Plant material}

Material of the Macaronesian Echinodium species was collected during field trips to the Azores and Madeira by the authors and by T. Pfeiffer (Greifswald). Material of E. hispidum was collected by J.-P. Frahm (Bonn) in New Zealand in the course of the BRYO AUSTRAL project. In addition, herbarium material of Echinodium from B, LISU, MADJ, and the private herbarium of A. Schäfer-Verwimp (Herdwangen-Schönach) was used. Voucher information and GenBank accession numbers for the Echinodium samples and further newly sequenced samples are listed in Table 1. Sequences from other pleurocarpous species were either taken from our previous studies or from GenBank (detailed information is available upon request), resulting in a data matrix comprising 62 specimens.

\section{DNA extraction, PCR and sequencing}

All plant material was thoroughly cleaned with distilled water and partly by ultrasonic treatment. Extraction of DNA, PCR amplification and manual or automated sequencing of the plastid $\operatorname{trn} L_{\mathrm{UAA}}$ intron and the nuclear ribosomal ITS1-5.8S-ITS2 region was performed as described in Quandt et al. (2007) and Sim-Sim et al. (2005).

\section{Alignment, sequence analysis and phylogenetic reconstructions}

Based on the criteria laid out in Kelchner (2000) and Quandt and Stech (2005), the DNA sequences were manually aligned using PhyDE $^{\circledR}$ v0.983 (Müller et al. 2006). Phylogenetic reconstructions using maximum parsimony (MP) or maximum likelihood (ML) principles were performed with PAUP $4.0 \mathrm{~b} 10$ (Swofford 2002). Three species of the Hookeriales were used as outgroup representatives, according to the sister group relationship of Hookeriales and Hypnales inferred in recent molecular analyses (e.g., Buck et al. 2000). Heuristic searches under parsimony were implemented using random sequence addition with 10 replicates and employing the default settings otherwise. In addition, the data set was analyzed using a simple indel coding (SIC) strategy (Simmons and Ochoterena 2000) as implemented in SeqState (Müller 2004a). SeqState generates a ready-to-use nexus file containing the sequence alignment with an automatically generated indel matrix appended. This file can be either executed directly in PAUP or submitted to PRAP (Müller 2004b) for ratchet and decay analyses. Heuristic bootstrap searches under parsimony were performed with 1000 
Table 1. Voucher information, geographic origin, and GenBank accession numbers of the Echinodium specimens and other newly sequenced samples

\begin{tabular}{|c|c|c|c|c|}
\hline \multirow[t]{2}{*}{ Taxon } & \multirow{2}{*}{$\begin{array}{l}\text { Geographic } \\
\text { origin }\end{array}$} & \multirow[t]{2}{*}{ Voucher no. (herbarium location) } & \multicolumn{2}{|c|}{ Accession no. } \\
\hline & & & $\operatorname{trn} L$ & ITS \\
\hline $\begin{array}{l}\text { Echinodium hispidum (Hook. f. \& Wils.) } \\
\text { Reichardt }\end{array}$ & New Zealand 1 & Frey \& Frey 94-162 (Frey) & EU434007 & EU477599 \\
\hline E. hispidum (Hook. f. \& Wils.) Reichardt & New Zealand 2 & Frahm 31-11 (Frey) & EU434009 & EU477601 \\
\hline E. hispidum (Hook. f. \& Wils.) Reichardt & New Zealand 3 & Vitt 2710 (B) & EU434008 & EU477600 \\
\hline E. prolixum (Mitt.) Broth. & Azores 1 & sub Sérgio 11810 (LISU) & EU434003 & EU477595 \\
\hline E. prolixum (Mitt.) Broth. & Azores 2 & Gabriel RG-011204/2 (LISU) & EU434006 & EU477598 \\
\hline E. prolixum (Mitt.) Broth. & Madeira 1 & Sim-Sim et al. Lev. 109 (LISU) & EU434004 & EU477596 \\
\hline E. prolixum (Mitt.) Broth. & Madeira 2 & Stech et al. 04-192 (L) & EU434005 & EU477597 \\
\hline E. renauldii (Card.) Broth. & Azores 1 & Pfeiffer 2003-98 (Pfeiffer) & EU434013 & EU477605 \\
\hline E. renauldii (Card.) Broth. & Azores 2 & Gabriel RG-011204/1 (LISU) & EU434014 & EU477606 \\
\hline E. setigerum (Mitt.) Jur. & Madeira & Lobo \& Santos 20.12 .04 (MADJ) & EU434015 & EU477607 \\
\hline E. spinosum (Mitt.) Jur. & Madeira 1 & Stech et al. 04-128 (L) & EU434011 & EU477603 \\
\hline E. spinosum (Mitt.) Jur. & Madeira 2 & Sim-Sim et al. s.n. (LISU) & EU434012 & EU477604 \\
\hline E. umbrosum (Mitt.) A. Jaeger & $?$ & (GenBank) & AF161137 & AY999172 \\
\hline $\begin{array}{l}\text { E. umbrosum var. glauco-viride (Mitt.) } \\
\text { Churchill }\end{array}$ & Norfolk Is. & $\begin{array}{l}\text { Streimann } 49634 \text { (Schäfer- } \\
\text { Verwimp) }\end{array}$ & EU434010 & EU477602 \\
\hline Neckera pennata Hedw. & $?$ & B300274526 (B) & EU503108 & EU503112 \\
\hline N. platyantha (Müll. Hal.) Paris & Rwanda & Pócs 6557 (Frey) & EU503109 & EU503113 \\
\hline $\begin{array}{l}\text { Thamnobryum alleghaniense (Müll. Hal.) } \\
\text { Nieuwl. }\end{array}$ & USA & $\begin{array}{l}\text { Miller } 14949 \text { (BONN, dupl. } \\
\text { NYS) }\end{array}$ & EU503110 & EU503114 \\
\hline Th. fasciculatum (Sw. ex Hedw.) I. Sastre & Colombia & B300265177 (B) & EU503111 & EU503115 \\
\hline
\end{tabular}

replicates, 10 random addition cycles per bootstrap replicate and the same options in effect. Decay values as further measurement of support for the individual clades were obtained using PRAP in combination with PAUP, employing the following ratchet settings: 10 random addition cycles of 200 iterations each with $25 \%$ upweighting of the characters in the iterations.

Maximum likelihood analyses were executed assuming a general time reversible model $(\mathrm{GTR}+\Gamma+\mathrm{I})$, and a rate variation among sites following a gamma distribution (four categories represented by mean). GTR $+\Gamma+\mathrm{I}$ was chosen as the model that best fits the data by Modeltest v3.6 (Posada and Crandall 1998) employing the Windows ${ }^{\circledR}$ interface MTgui (Nuin 2005). The settings proposed by Modeltest v3.6 were executed in PAUP 4.0b10. For the combined data set the following

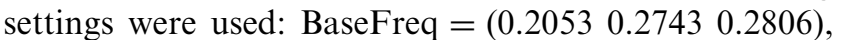
Nst $=6, \quad$ Rmatrix $=\left(\begin{array}{llll}1.0000 & 3.3710 & 0.8191 & 0.8191\end{array}\right.$ 4.4120), Shape $=0.6679$, and Pinvar $=0.3827$. Likelihood bootstrap searches were performed with 500 replicates using the 'fast bootstrap' option (bootstrapping without branch-swapping).

For further measurement of clade support posterior probabilities were calculated using MrBayes V3.1 (Huelsenbeck and Ronquist 2001). As in the ML analysis, the GTR model of nucleotide substitution was employed, assuming site-specific rate categories following a gamma distribution. The a priori probabil- ities supplied were those specified in the default settings of the program. Posterior probability (PP) distributions of trees were created using the Metropolis-coupled Markov chain Monte Carlo (MCMCMC) method and following the search strategies suggested by Huelsenbeck et al. (2001, 2002). To allow for possible deviating substitution models for the different regions, the data set was divided into four partitions. Four runs with four chains $\left(10^{6}\right.$ generations each) were run simultaneously, with the temperature of the single heated chain set to 0.2 . Chains were sampled every 10 generations and the respective trees written to a tree file. Calculations of the consensus tree and of the posterior probability of clades were performed based upon the trees sampled after the chains converged (we used $25 \%$ as default). Consensus topologies and support values from the different methodological approaches were compiled and drawn using TreeGraph 1.0 (Müller and Müller 2004).

\section{Results}

\section{Sequence characterisation and alignment}

Features characteristic for the pleurocarpous Hypnales, such as low sequence variation and a short middle part of the intron (stem-loop region P8 in the respective secondary structure; cf. Quandt and Stech 2005) 
were also observed in all Echinodium species. The length of the trnL intron in Echinodium was either 265 nucleotides (nt) (E. hispidum, E. prolixum, E. umbrosum), the typical length among pleurocarpous mosses, or 254 nt (E. renauldii, E. setigerum, E. spinosum), i.e., the latter species were characterised by an $11 \mathrm{nt}$ deletion located in P8. The trnL intron alignment of the 62 compiled sequences of pleurocarpous mosses comprised 357 positions.

In bryophytes, the nuclear ribosomal spacers (ITS1 and ITS2) are generally more variable than the $\operatorname{trn} L$ intron, with a higher degree of length variation (e.g., Stech et al. 2003; Vanderpoorten et al. 2006). In Echinodium, sequence lengths of the ITS1-5.8S-ITS2 region ranged from $674 \mathrm{nt}$ (E. renauldii, E. setigerum, E. spinosum) to $690 \mathrm{nt}$ (E. prolixum) and $701 \mathrm{nt}$ (E. hispidum, E. umbrosum), respectively. The ITS sequence alignment of all included pleurocarpous mosses comprised 1317 positions.

Of the 1674 positions in the combined $\operatorname{trnL} / \mathrm{ITS}$ alignment, 445 (26.6\%) were variable, and 277 (16.5\%, or $62.2 \%$ of the variable positions) were parsimonyinformative. The simple indel coding approach yielded another 269 parsimony-informative characters, resulting in a total of 546 parsimony-informative characters.

\section{Phylogenetic analysis}

The MP analysis employing the parsimony ratchet retained 6 trees (length 1091, CI 0.529, RI 0.708, RC 0.374). After inclusion of the indel matrix, four trees were retained (length 1863 , CI 0.575 , RI 0.732, RC 0.421), of which the strict consensus is shown in Fig. 2, with bootstrap support values (BS) and decay indices (DI) indicated on the branches. Values above the branches are based upon the sequence matrix only, whereas the values below were obtained when the indel matrix was included in the analyses. In the ML analysis, three optimal trees were found $(\ln L=-8073.31622)$, which were identical except for slight variation within the poorly resolved branch of Echinodium renauldii, $E$. setigerum, and E. spinosum. One of these trees is shown in Fig. 3, with ML bootstrap values indicated above the branches and significant $(\geq 94)$ posterior probabilities (PP) below. For most branches no or only slight differences in PP values were observed when the indel matrix was included in the analysis. However, three branches were only significantly supported without indel coding, whereas eight branches received significant PP values only with indel coding.

In all analyses the Echinodium species are divided into three separate clades. The Macaronesian species $E$. renauldii, E. setigerum, and E. spinosum are closely related to each other (99-100\% BS, DI 13-16, PP 100) (Figs. 2 and 3), but relationships to other genera and families are ambiguous. A sistergroup relationship with Orthostichella is indicated in the parsimony analysis with the indel matrix included, but weakly supported (58\% BS; Fig. 2). The remaining Macaronesian species, E. prolixum, is nested within Isothecium in the wellsupported Lembophyllaceae clade. In particular, a clade comprising E. prolixum and I. myosuroides Brid. receives maximal BS and PP support. The closely related samples of E. hispidum and E. umbrosum (95-98\% BS, DI 4-6, PP 100) are nested within Thamnobryum in the Neckeraceae. Their sistergroup relationship with $T$. pandum (Hook. f. \& Wilson) I.G. Stone \& G.A.M. Scott from New Zealand and T. fasciculatum (Sw. ex Hedw.) I. Sastre from the Neotropics is less well supported.

\section{Discussion}

The molecular data provide clear evidence for polyphyly of Echinodium and thus support the suspicion of Churchill (1986) that some Echinodium species might belong to other genera. Three molecular groups are significantly supported: the first comprises three of the four Macaronesian species (E. renauldii, E. setigerum, and $E$. spinosum), the second the remaining Macaronesian species $E$. prolixum (together with Isothecium myosuroides), and the third the Australasian species $E$. hispidum and E. umbrosum. Similar results were obtained by a preliminary analysis of a smaller data set using $r b c L$ sequences (data not shown).

The species of the first group are closely related, not only at the molecular level, but also morphologically (cf. Table 2). In particular E. spinosum and E. setigerum are sometimes difficult to distinguish at first sight (Fontinha et al. 2001). Furthermore, all three species are largely confined to shady and humid narrow valleys of the laurel forest; E. renauldii was also collected at lower altitudes at cave entrances (González-Mancebo et al. 1991). Concerning the substrates, E. spinosum occasionally occurs on soil or as an epiphyte, whereas E. renauldii and E. setigerum are strictly epilithic except

Fig. 2. Strict consensus of four most parsimonious trees showing relationships of the genus Echinodium (in grey shading) within the pleurocarpous moss order Hypnales. Combined analysis of plastid $\operatorname{trnL}$ intron and nuclear ribosomal ITS sequences evaluated with PAUP 4.0b10, employing the parsimony ratchet and simple indel coding according to Simmons and Ochoterena (2000). Bootstrap support values and decay indices indicated on branches. Values above branches based upon sequence matrix only; values below branches obtained when indel matrix was included. 


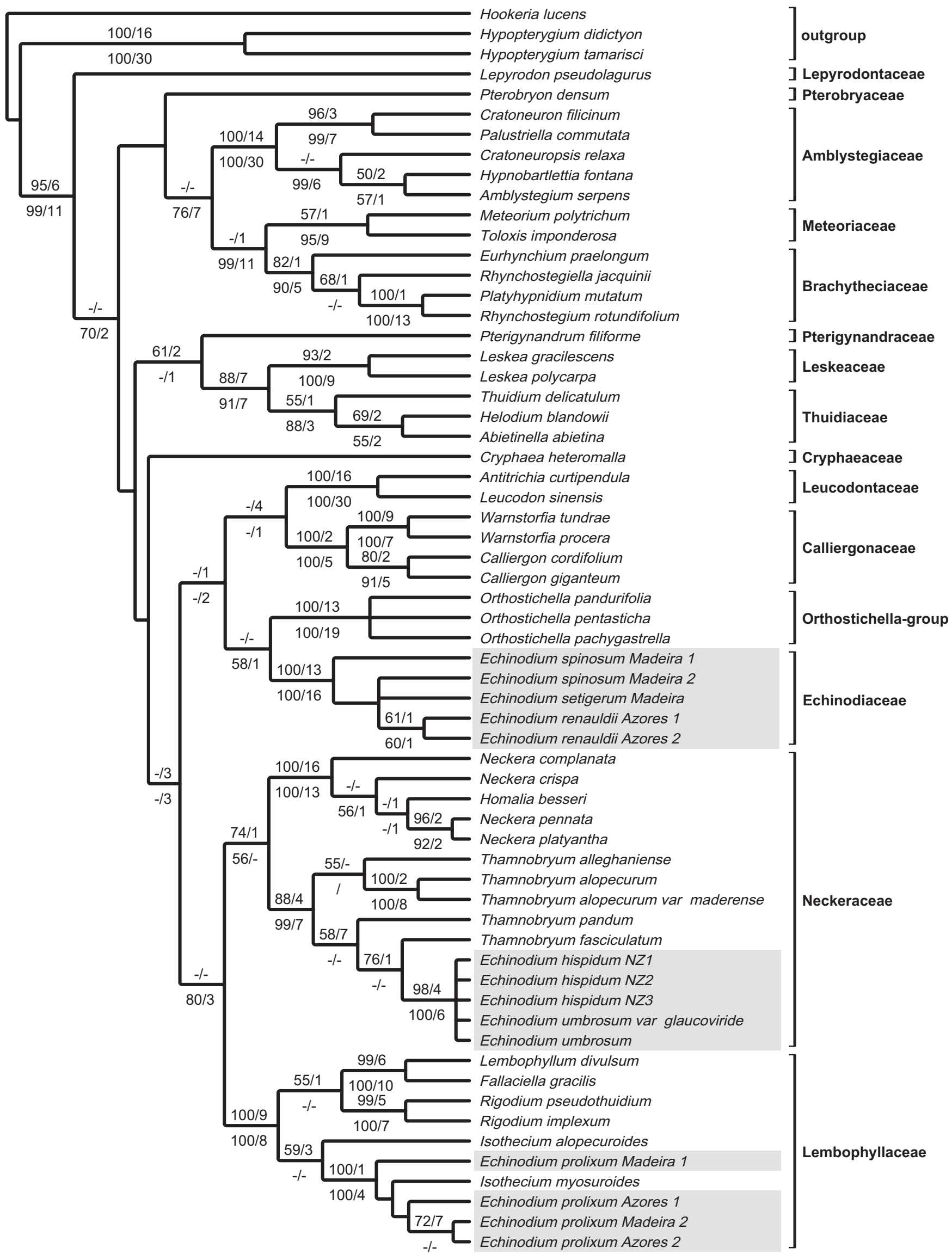


for one collection of the former species on a stem base. On Madeira island, E. spinosum and especially E. setigerum are linked to the Clethro arboreae-Ocoteetum foetentis vascular plant community (Capelo et al. 2000), the latter being restricted to few valleys of wellconserved laurel forest. Possibly, E. renauldii and $E$. setigerum evolved from $E$. spinosum under specific environmental conditions in epilithic microhabitats in the laurel forests of Madeira and the Azores, respectively. As Echinodium spinosum is the type species of the genus, and because no close relationships with other included pleurocarpous genera and families were observed in the molecular trees (Figs. 2 and 3), the three species represent what remains of Echinodium (Echinodiaceae). Their unsupported sistergroup relationship with Orthostichella in the parsimony analysis (Fig. 2) needs further investigation of a larger set of pleurocarpous taxa. Orthostichella is a segregate of Lembophyllaceae that was placed in Neckeraceae in a recent morphological revision (Allen and Magill 2007), but probably constitutes a separate family according to the molecular data.

Echinodium prolixum is distinguished from the other Macaronesian (and Australasian) species not only at the molecular level, but also morphologically by the leaf shape, the costa ending noticeably before the leaf apex (cf. Table 2), and by its wider ecological amplitude. In Madeira and the Azores, it is the most abundant species of the genus and occurs on several substrates, such as rock, soil, and bark (see, for example, Gabriel and Bates 2005). In Madeira, E. prolixum can be found in the laurel forest, in heathlands at higher elevations (Vaccinio padifoli-Ericetum maderinicolae and Polysticho falcinelliEricetum arboreae vascular plant communities; Capelo et al. 2000) as well as in semi-natural forest types. For this species, the affinity with the Lembophyllaceae proposed by Hedenäs (1992) is well supported by the present molecular analyses. By noting morphological similarities between high mountain phenotypes of E. prolixum and Isothecium holtii Kindb. in Madeira, Hedenäs (1992) also provided morphological support for the transfer of E. prolixum to Isothecium, which is made here (see Taxonomy section). Thus, the evolutionary history of E. prolixum has to be discussed in the course of phylogenetic analyses of Isothecium and the Lembophyllaceae in general. However, recent molecular data were partly incongruent with the morphological circumscription of Isothecium species (Draper et al. 2007), and further molecular analyses including E. prolixum have to be carried out to infer its affinities and taxonomic status.

The position of the Australasian species E. hispidum and E. umbrosum within the Thamnobryum clade (Figs. 2 and 3) is in accordance with the molecular study of Buck et al. (2000), which, however, included only E. umbrosum, but is more difficult to interpret on morphological grounds. A comparison of gametophytic characters indicates that E. hispidum and E. umbrosum are somewhat intermediate between Echinodium s.str. and Thamnobryum (Table 2). Ecologically, E. hispidum does share with many Thamnobryum spp. the preference for wet and aquatic habitats. At least for this species, the long subulate leaves with partially to fully bistratose margins enhancing mechanical stability may be an adaptation to aquatic environments, a phenomenon also found in Thamnobryum, e.g., in the Madeiran endemic T. fernandesii Sérgio (cf. Hedenäs 1992). However, as with E. prolixum, the affinities of E. umbrosum and E. hispidum have to be treated in the context of a more detailed phylogenetic analysis of the Neckeraceae, which is beyond the scope of this paper.

The present molecular study bears important consequences for the understanding of the evolutionary history of Echinodium and the explanation of the extant distribution pattern. Churchill (1986) noted that the Macaronesian-Australasian disjunct distribution of Echinodium as a natural taxon would be exceptionally noteworthy, but that questions over the monophyly of the genus meant that biogeographic conclusions should be treated with caution. In fact, the polyphyly of Echinodium indicated by the present molecular data clearly suggests that the distribution pattern based on the morphology of Macaronesian and Australasian plants is an artefact of independent evolutionary events. Nevertheless, the novel occurrence of a suite of morphological characters not typical for taxa included in well-supported clades amongst the Hypnalean pleurocarps requires some explanation. This could imply either that a set of plesiomorphic characters (irregularly pinnate to subdendroid branching, subulate leaves with percurrent to excurrent costae, short leaf cells) was retained in unrelated groups in relict habitats in Macaronesia and Australasia, or that parallel morphological evolution of the 'Echinodium habit' took place in both geographic regions. Of these hypotheses, the evolutionary parallelism scenario seems more plausible for several reasons. Firstly, the genus Bescherellia of the Hypnodendrales is morphologically very similar to Echinodium, except that the costa is differentiated in cross-section, and also occurs in similar habitats. However, Bescherellia is regarded as quite derived within the hypnodendroid pleurocarps, which are sister to the homocostate pleurocarps to which the Hypnales belong (cf. Bell et al. 2007). Secondly, according to molecular dating (Newton et al. 2007), the diversification of major lineages within the Hypnales leading to extant genera had already taken place by the Early to Late Cretaceous (mainly between ca. 130 and 80 mya) and therefore much earlier than the oldest fossil records of Echinodium (cf. Fig. 1). Furthermore, none of the families that may represent basal lineages in the Hypnales according to molecular phylogenies, e.g., 


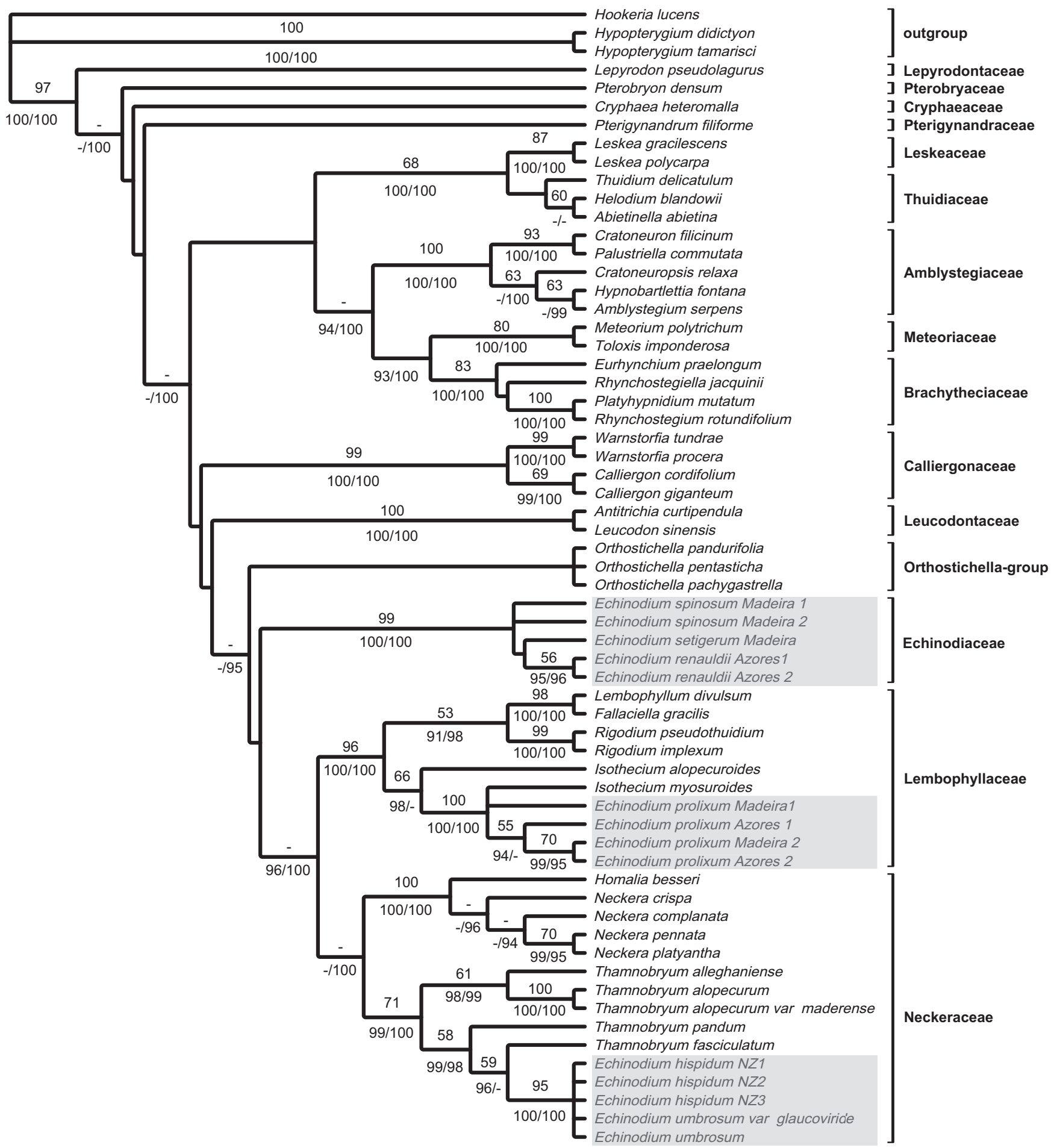

Fig. 3. One out of three optimal maximum likelihood trees (GTR $+\Gamma+\mathrm{I}$ model) based on combined plastid trnL intron and nuclear ribosomal ITS sequences, showing relationships of the genus Echinodium (in grey shading) within the pleurocarpous moss order Hypnales. Likelihood bootstrap values indicated above branches; significant $(\geq 94)$ posterior probabilities (without/with simple indel coding) below branches.

Fontinalaceae, Fabroniaceae, Plagiotheciaceae, or Stereophyllaceae (e.g., Buck et al. 2000; Tsubota et al. 2004; Ignatov et al. 2007), show the combination of characters attributed to the 'Echinodium habit'. Thirdly, the Echinodium fossils from Tasmania are of only
Pleistocenic age, and at least the extant Australasian Echinodium species could be the result of a rather recent parallel evolution in aquatic environments. However, as they are related with Thamnobryum according to the present molecular data, E. hispidum and E. umbrosum, 
Table 2. Comparison of gametophytic characters in Echinodium, Isothecium, and Thamnobryum

\begin{tabular}{|c|c|c|c|c|c|}
\hline Taxon character & $\begin{array}{l}\text { Echinodium s.str. } \\
\text { (E. renauldii, } \\
\text { E. setigerum, } \\
\text { E. spinosum) }\end{array}$ & $\begin{array}{l}\text { Echinodium } \\
\text { hispidum/ } \\
\text { E. umbrosum }\end{array}$ & $\begin{array}{l}\text { Thamnobryum } \\
\text { spp. }\end{array}$ & $\begin{array}{l}\text { Echinodium } \\
\text { prolixum }\end{array}$ & Isothecium spp. \\
\hline $\begin{array}{l}\text { Branching of } \\
\text { secondary stems }\end{array}$ & $\begin{array}{l}\text { Irregularly pinnate or } \\
\text { sub-dendroid }\end{array}$ & Irregularly pinnate & $\begin{array}{l}\text { Irregularly } \\
\text { pinnate to often } \\
\text { frondose or } \\
\text { dendroid }\end{array}$ & $\begin{array}{l}\text { Irregularly } \\
\text { pinnate or sub- } \\
\text { dendroid }\end{array}$ & $\begin{array}{l}\text { Irregularly pinnate } \\
\text { or sub-dendroid }\end{array}$ \\
\hline $\begin{array}{l}\text { Leaf shape } \\
\text { (leaves of } \\
\text { secondary } \\
\text { stems) }\end{array}$ & $\begin{array}{l}\text { Subulate from ovate } \\
\text { or triangular base }\end{array}$ & $\begin{array}{l}\text { Broadly linear- } \\
\text { lanceolate or } \\
\text { subulate from ovate } \\
\text { or triangular base }\end{array}$ & $\begin{array}{l}\text { Ovate to } \\
\text { lanceolate }\end{array}$ & $\begin{array}{l}\text { Broadly } \\
\text { lanceolate to } \\
\text { ovate-triangular }\end{array}$ & $\begin{array}{l}\text { Broadly ovate to } \\
\text { long-triangular }\end{array}$ \\
\hline Leaf plication & Plicate & Plicate or indistinct & Not plicate & Plicate & Not plicate \\
\hline $\begin{array}{l}\text { Upper leaf } \\
\text { margins }\end{array}$ & $\begin{array}{l}\text { Entire (awn toothed } \\
\text { in E. spinosum) }\end{array}$ & Entire or serrulate & Often serrate & Serrulate & Serrulate \\
\hline Leaf lamina & $\begin{array}{l}\text { Margins bi- or } \\
\text { pluristratose, other } \\
\text { lamina uni- or } \\
\text { bistratose }\end{array}$ & $\begin{array}{l}\text { Margins bi- or } \\
\text { pluristratose, other } \\
\text { lamina uni- or bi- } \\
\text { to pluristratose }\end{array}$ & $\begin{array}{l}\text { Uni- to } \\
\text { variously bi- or } \\
\text { pluristratose }\end{array}$ & $\begin{array}{l}\text { Sometimes small } \\
\text { portions } \\
\text { bistratose }\end{array}$ & Unistratose \\
\hline $\begin{array}{l}\text { Shape of median } \\
\text { lamina cells }\end{array}$ & $\begin{array}{l}\text { Isodiametric to } \\
\text { oblong }\end{array}$ & $\begin{array}{l}\text { Isodiametric to } \\
\text { oblong }\end{array}$ & $\begin{array}{l}\text { Isodiametric to } \\
\text { rhomboidal }\end{array}$ & $\begin{array}{l}\text { Rhomboidal to } \\
\text { linear }\end{array}$ & $\begin{array}{l}\text { Rhomboidal to } \\
\text { linear }\end{array}$ \\
\hline $\begin{array}{l}\text { Ornamentation } \\
\text { of median } \\
\text { lamina cells }\end{array}$ & Smooth & $\begin{array}{l}\text { Smooth or } \\
\text { papillose }\end{array}$ & $\begin{array}{l}\text { Smooth or } \\
\text { papillose }\end{array}$ & Smooth & $\begin{array}{l}\text { Smooth or } \\
\text { abaxially prorate }\end{array}$ \\
\hline Alar cells & $\begin{array}{l}\text { In small and often } \\
\text { auriculate group }\end{array}$ & Not differentiated & $\begin{array}{l}\text { Few, not } \\
\text { sharply } \\
\text { delimited }\end{array}$ & $\begin{array}{l}\text { Basal and alar } \\
\text { cells similarly } \\
\text { differentiated } \\
\text { (in stem leaves } \\
\text { alar groups } \\
\text { more similar to } \\
\text { Isothecium) }\end{array}$ & $\begin{array}{l}\text { In indistinct } \\
\text { auriculate group }\end{array}$ \\
\hline Costa & Long-excurrent & $\begin{array}{l}\text { Percurrent to long- } \\
\text { excurrent }\end{array}$ & Subpercurrent & $\begin{array}{l}\text { Ending in upper } \\
1 / 3 \text { of leaf, well } \\
\text { below leaf apex }\end{array}$ & $\begin{array}{l}\text { Ending at mid-leaf } \\
\text { or in upper half of } \\
\text { leaf }\end{array}$ \\
\hline
\end{tabular}

like Thamnobryum in general, probably represent the most primitive elements within Neckeraceae (e.g., Enroth 1994).

\section{Taxonomy}

Isothecium prolixum (Mitt.) Stech, Sim-Sim, Tangney \& D. Quandt, comb. nov.

Basionym: Leskea prolixa Mitt. Journal of the Proceedings of the Linnean Society 8: 7. 1. 1864.

Echinodium prolixum (Mitt.) Broth. Die Natürlichen Pflanzenfamilien I(3): 1217. 1909.

Thamnobryum hispidum (Hook. f. \& Wilson) Stech, Sim-Sim, Tangney \& D. Quandt, comb. nov.

Basionym: Hypnum hispidum Hook. f. \& Wilson. London Journal of Botany 3: 552. 1844.
Echinodium hispidum (Hook. f. \& Wilson) Reichardt. Reise der Österreichischen Fregatte Novara um die Erde 1(3): 127.1870.

\section{Thamnobryum umbrosum (Mitt.) Stech, Sim-Sim, Tangney \& D. Quandt, comb. nov.}

Basionym: Leskea umbrosa Mitt. Journal of the Proceedings of the Linnean Society 4: 92. 1859.

Echinodium umbrosum (Mitt.) A. Jaeger. Bericht über die Thätigkeit der St. Gallischen Naturwissenschaftlichen Gesellschaft 1876-1877: 314 (Gen. Sp. Musc. 2: 1132). 1878.

Thamnobryum umbrosum var. glauco-viride (Mitt.) Stech, Sim-Sim, Tangney \& D. Quandt, comb. nov.

Basionym: Hypnum glaucoviride Mitt. Handbook of the New Zealand Flora 473. 1867. 
Echinodium umbrosum var. glauco-viride (Mitt.) S.P. Churchill. Journal of Bryology 14: 129. 1986.

\section{Acknowledgements}

Sincere thanks are due to W. Frey, L. Hedenäs, T. Pfeiffer and three reviewers for comments on the manuscript; to H. Nowak-Krawietz (B), J.-P. Frahm and A. Schäfer-Verwimp for providing plant material; and to B. Giesicke for technical assistance. Funding by the Deutsche Forschungsgemeinschaft (DFG, QU 153/ 3-1), the Deutscher Akademischer Austauschdienst (DAAD, PPP project D/03/40407) and the Portuguese project POCI/AGR/57487/2004 is greatly acknowledged.

\section{References}

Abramov, A.L., Abramov, I.I., 1958. On certain genetic relations among the fossil mosses of the flora of Duab (Abkhazia). Bot. Zhurn. USSR 43, 1018-1024.

Allen, B.H., Magill, R.E., 2007. A revision of Orthostichella (Neckeraceae). Bryologist 110, 1-45.

Brotherus, V.F., 1925. Musci (Laubmoose), 2. Hälfte. In: Engler, A., Prantl, K. (Eds.), Die Natürlichen Pflanzenfamilien. Engelmann, Leipzig, pp. 1-542.

Bell, N.E., Quandt, D., O’Brien, T.J., Newton, A.E., 2007. Taxonomy and phylogeny in the earliest diverging pleurocarps: square holes and bifurcating pegs. Bryologist 110, 533-560.

Buck, W.R., Vitt, D.H., 1986. Suggestions for a new familial classification of pleurocarpous mosses. Taxon 35, 21-60.

Buck, W.R., Goffinet, B., Shaw, A.J., 2000. Testing morphological concepts of orders of pleurocarpous mosses (Bryophyta) using phylogenetic reconstructions based on trnL-trnF and rps4 sequences. Mol. Phyl. Evol. 16, 180-198.

Capelo, J., Costa, J.C., Lousã, M., Fontinha, S., Jardim, R., Sequeira, M., Rivas-Martínez, S., 2000. Vegetação da Madeira (Portugal). I. Aproximação à tipologia fitossociológica. Silva Lus 7, 257-282.

Capelo, J., Sequeira, M., Jardim, R., Mesquita, S., Costa, J.C., 2005. The vegetation of Madeira Island (Portugal). A brief overview and excursion guide. Quercetea 7, 95-122.

Churchill, S.P., 1986. A revision of Echinodium Jur. (Echinodiaceae: Hypnobryales). J. Bryol. 14, 117-133.

De Luna, E., Buck, W.R., Akiyama, H., Arikawa, T., Tsubota, H., Gonzalez, D., Newton, A.E., Shaw, A.J., 2000. Ordinal phylogeny within the Hypnobryalean pleurocarpous mosses inferred from cladistic analyses of three chloroplast DNA sequence data sets: $\operatorname{trn} L-F, \operatorname{rps} 4$, and rbcL. Bryologist 103, 242-256.

Dierßen, K., 2001. Distribution, ecological amplitude and phytosociological characterization of European bryophytes. Bryophyt. Bibl. 56, 1-289.

Draper, I., Hedenäs, L., Grimm, G.W., 2007. Molecular and morphological incongruence in European species of Isothecium (Bryophyta). Mol. Phyl. Evol. 42, 700-716.
ECCB, 1995. Red Data Book of European Bryophytes. European Committee for Conservation of Bryophytes, Trondheim.

Enroth, J., 1994. On the evolution and circumscription of the Neckeraceae (Musci). J. Hattori Bot. Lab. 76, 13-20.

Fleischer, M., 1909-1923. Die Musci der Flora von Buitenzorg. E.J. Brill, Leiden.

Fontinha, S., Sim-Sim, M., Sérgio, C., Hedenäs, L., 2001. Briófitos endémicos da Madeira. In: DRAmb SRA (Ed.), Biodiversidade Madeirense: Avaliação e Conservação. Madeira, Portugal, pp. 1-51.

Fontinha, S., Sim-Sim, M., Lobo, C., 2006. The bryophytes of the Laurisilva of Madeira. Guide to Some Species. SRARN, SPNM, e FFCUL e CEBVFCUL, Portugal.

Frahm, J.-P., 2004. A new contribution to the moss flora of Baltic and Saxon amber. Rev. Palaeobot. Palynol. 129, 81-101.

Gabriel, R., 1994. Briófitos da Ilha Terceira (Açores). Ecologia, Distribução e Vulnerabilidade de Espécies Seleccionadas. Thesis, Universidade dos Açores.

Gabriel, R., Bates, J.W., 2005. Bryophyte community composition and habitat specificity in the natural forests of Terceira, Azores. Plant Ecol. 177, 125-144.

Goffinet, B., Buck, W.R., 2004. Systematics of the Bryophyta (mosses): from molecules to a revised classifcation. In: Goffinet, B., Hollowell, V., Magill, R. (Eds.), Molecular Systematics of Bryophytes. Monogr. Syst. Bot. Missouri Bot. Gard. 98, 205-239.

González-Mancebo, J.M., Losada-Lima, A., HérnandezGarcia, C.D., 1991. A contribution to the floristic knowledge of caves on the Azores. Mém. Biospéol. 17, 219-226.

Hedenäs, L., 1992. Flora of Madeiran pleurocarpous mosses (Isobryales, Hypnobryales, Hookeriales). Bryophyt. Bibl. 44, 1-165.

Hedenäs, L., 1995. Higher taxonomic level relationships among diplolepidous pleurocarpous mosses - a cladistic overview. J. Bryol. 18, 723-781.

Huelsenbeck, J.P., Ronquist, F., 2001. MrBayes: Bayesian inference of phylogenetic trees. Bioinformatics 17, 754-755.

Huelsenbeck, J.P., Ronquist, F., Nielsen, R., Bollback, J.P., 2001. Bayesian inference of phylogeny and its impact on evolutionary biology. Science 294, 2310-2314.

Huelsenbeck, J.P., Larget, B., Miller, R.E., Ronquist, F., 2002. Potential applications and pitfalls of Bayesian inference of phylogeny. Syst. Biol. 51, 673-688.

Ignatov, M.S., Gardiner, A.A., Bobrova, V.K., Milyutina, I.A., Huttunen, S., Troitsky, A.V., 2007. On the relationships of mosses of the order Hypnales, with special reference to taxa traditionally classified in the Leskeaceae. In: Newton, A.E., Tangney, R.S. (Eds.), Pleurocarpous Mosses, Systematics and Evolution. Syst. Assoc. Spec. Vol. 71, 177-213.

IUCN, 2002. The 2000 IUCN World Red List of Bryophytes. International Union for the Conservation of Nature (IUCN). $\langle$ http://www.artdata.slu.se/guest/SSCBryo/WorldBryo.htm $\rangle$.

Jordan, G.J., Dalton, P.J., 1995. Mosses from Early Pleistocene sediments in western Tasmania. Alcheringa 19, 291-296.

Kelchner, S.A., 2000. The evolution of non-coding chloroplast DNA and its application in plant systematics. Ann. Missouri Bot. Gard. 87, 482-498. 
Lancucka-Srodoniowa, M., 1996. Tortonian flora from the "Gdow Bay" in the South of Poland. Acta Palaeobot. 7, $1-135$.

Müller, K., 2004a. SeqState - primer design and sequence statistics for phylogenetic DNA data sets. Appl. Bioinformatics 4, 65-69.

Müller, K., 2004b. PRAP - calculation of Bremer support for large data sets. Mol. Phyl. Evol. 31, 780-782.

Müller, J., Müller, K., 2004. TreeGraph: automated drawing of complex tree figures using an extensible tree description format. Mol. Ecol. Notes 4, 786-788.

Müller, K., Müller, J., Neinhuis, C., Quandt, D., 2006. PhyDE - Phylogenetic Data Editor, v0.983. Program distributed by the authors. 〈http://www.phyde.de〉.

Newton, A.E., Wikström, N., Bell., N., Forrest, L.L., Ignatov, M.S., 2007. Dating the diversification of the pleurocarpous mosses. In: Newton, A.E., Tangney, R.S. (Eds.), Pleurocarpous Mosses, Systematics and Evolution. Syst. Assoc. Spec. Vol. 71, 337-366.

Nuin, P.A.S., 2005. Mtgui - A Simple Interface to ModelTest. Program distributed by the author. University of Toronto. $\langle$ http://www.genedrift.org/mtgui.php $\rangle$.

Posada, D., Crandall, K.A., 1998. Modeltest: testing the model of DNA substitution. Bioinformatics 14, 817-818.

Quandt, D., Stech, M., 2005. Molecular evolution and secondary structure of the chloroplast trnL intron in bryophytes. Mol. Phyl. Evol. 36, 429-443.

Quandt, D., Bell, N., Stech, M., 2007. Unravelling the knot: Pulchrinodaceae, fam. nov. (Bryales). In: Kürschner, H., Pfeiffer, T., Stech, M. (Eds.), A Festschrift to Wolfgang Frey - a scientist's life between 'deserts' and 'rain forests'. Nova Hedwigia Beih. 131, 21-39.

Robinson, H., 1971. A revised classification for the orders and families of mosses. Phytologia 21, 289-293.
Simmons, M.P., Ochoterena, H., 2000. Gaps as characters in sequence-based phylogenetic analyses. Syst. Biol. 49, 369-381.

Sim-Sim, M., Stech, M., Esquível, M.G., Figueiredo, A.C., Costa, M.M., Barroso, J.G., Pedro, L.G., Fontinha, S., Lobo, C., 2005. Plagiochila spinulosa (Dicks.) Dumort. (Plagiochilaceae, Hepaticophytina) in Madeira Island morphological, phytochemical, and molecular evidence. J. Hattori Bot. Lab. 98, 131-147.

Stech, M., Quandt, D., Lindlar, A., Frahm, J.-P., 2003. The systematic position of Pulchrinodus inflatus (Pterobryaceae, Bryopsida) based on molecular data. Studies in austral temperate rain forest bryophytes 21 . Aust. Syst. Bot. 16, 561-568.

Swofford, D.L., 2002. PAUP*: Phylogenetic Analysis Using Parsimony (*and Other Methods), version 4.0b10. Sinauer Associates Inc., Sunderland, MA.

Tsubota, H., De Luna, E., González, D., Ignatov, M.S., Deguchi, H., 2004. Molecular phylogenetics and ordinal relationships based on analyses of a large-scale data set of $600 \mathrm{rbcL}$ sequences of mosses. Hikobia 14, 149-170.

Vanderpoorten, A., Goffinet, B., Quandt, D., 2006. Utility of the internal transcribed spacers of the $18 \mathrm{~S}-5.8 \mathrm{~S}-26 \mathrm{~S}$ nuclear ribosomal DNA in plant systematics. In: Sharma, A.K., Sharma, A. (Eds.), Plant Genome: Biodiversity and Evolution, vol. 2B. Science Publishers, Enfield, NH, pp. 385-407.

Vitt, D.H., 1984. Classification of the Bryopsida. In: Schuster, R.M. (Ed.), New Manual of Bryology, vol. 2. Hattori Botanical Laboratory, Nichinan, pp. 696-759.

Walther, K., 1983. Bryophytina. Laubmoose. In: Gerloff, J., Poelt, J. (Eds.), Syllabus der Pflanzenfamilien, 13. Aufl., Gebrüder Bornträger, Berlin, pp. 1-108. 